\title{
Baseline Serum Chemistry, Hematology, and Serology Assessment in Black Bears (Ursus americanus) and Grizzly Bears (Ursus arctos horribilis) at a Rehabilitation Center in British Columbia
}

\author{
Sara Heslop, DVM CANDidate \\ FLORINA TSENG, DVM \\ Cummings School of Veterinary Medicine \\ TUFTS UNIVERSITY \\ North Grafton, Massachusetts
}

\begin{abstract}
Health assessments contribute toward an understanding of nutritional well being and disease occurrence in bears kept in captivity for rehabilitation and increase awareness of what pathogens potentially are being released along with their hosts in reintroduction situations. The Northern Lights Wildlife Shelter in Smithers, British Columbia, rehabilitates orphaned black bear cubs and is the first shelter to be permitted to rehabilitate grizzly cubs in a collaborative pilot project with the International Fund for Animal Welfare and British Columbia Ministry of Environment. Blood was collected from two grizzly bear yearlings, six black bear yearlings, and three black bear cubs housed at the shelter in 2009 for serology and hematology. The bears were tested for canine distemper, canine adenovirus 1 and 2, leptospirosis, and toxoplasmosis. Additionally, standard serum chemistries and leukocyte differentials were completed. All of the bears were negative for the infectious diseases, but showed increased levels of eosinophilia suggestive of parasitic disease and a few serum values outside of the International Species Information System (ISIS) and IDEXX reference ranges. The blood and serum values collected in this study serve as the beginning of a hematologic baseline and measurement of disease prevalence in grizzly and black bear cubs brought to the shelter for rehabilitation.
\end{abstract}

Keywords: black bear, grizzly bear, serum chemistry, serology, hematology, canine distemper, leptospirosis, toxoplasmosis, canine adenovirus

\section{INTRODUCTION}

Grizzly bears, Ursus arctos horribilis, were once widespread across Canada, northern Mexico, and the US. The grizzly is a subspecies of the brown bear that also is found in Europe and northern Asia. The grizzly's historic range has dwindled as human development has expanded in North America. Under the influence

Sara Heslop is a veterinary student at Tufts University Cummings School Veterinary Medicine.

Dr. Tseng is an Assistant Professor and Director of the Wildlife Clinic at Tufts Cummings School of Veterinary Medicine. She is a former NWRA vice president and board member. of human hunting, extermination of 'nuisance bears,' traffic, and habitat fragmentation, the grizzly has lost an estimated 50 percent of its range and abundance since the mid-1800s. The grizzly is currently listed on Appendix II of the Convention on the International Trade in Endangered Species (CITES), has been extirpated in much of the US and its prior prairie habitat in Canada, and is listed as a species of special concern in the remaining Canadian population according to the Canadian government's Species at Risk Public Registry (SARA). It is estimated that there are approximately 26,000 grizzlies left in Canada and over half of these animals (more than 14,000) are found in British Columbia (BC) (COSEWIC 2002). Although $\mathrm{BC}$ contains a large percentage of the remaining grizzlies in Canada, their historical range in the province has shrunk and the remaining population is at risk of continued decline. The Northern Cascade population is considered threatened in both BC and Washington State, with only an estimated 25 animals remaining. Grizzlies elsewhere in the province are Blue listed to avoid continued population decline (MELP 2004).

The viability of grizzly bear populations is threatened by human encroachment, which reduces and fragments their remaining habitat and isolates the remaining populations from each other. In fact, human activity including road kills, hunting, and poaching, is responsible for the majority of grizzly deaths. According to the Canadian SARA, over 450 grizzlies are hunted legally in Canada each year and more are killed without being reported. Some are killed in self-defense during perceived or real attacks; 


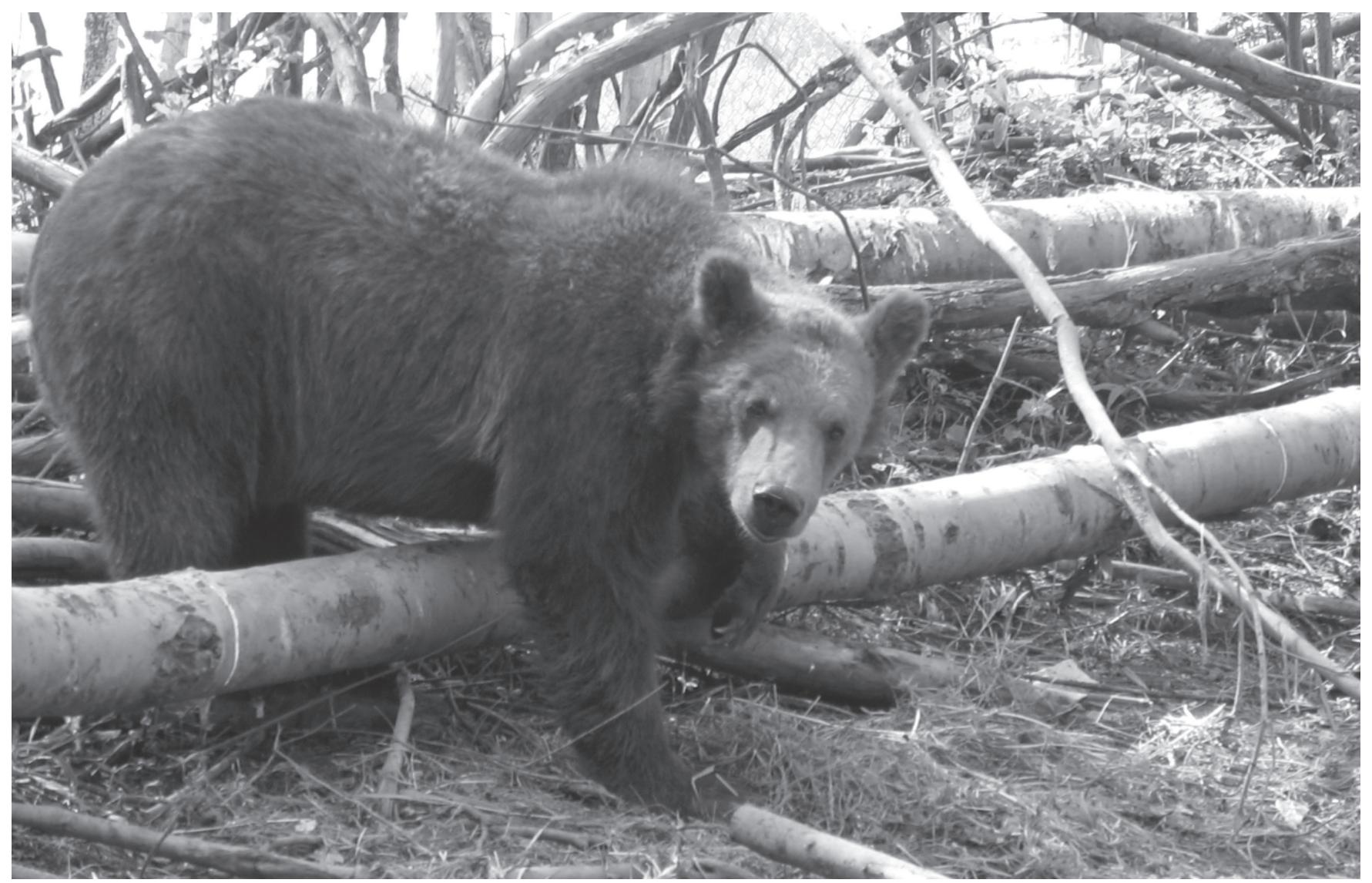

Grizzly bear (Ursus arctos horribilis) foraging in the NLWS enclosure.

others are labeled 'nuisance' or 'problem' bears when they become habituated and begin to utilize human food sources, such as garbage dumps, homes, camps, and orchards for food, or to predate on livestock. These bears often are killed when these activities bring them into conflict with people. Habitat fragmentation increases the risk to each pocket of grizzlies because they become genetically and geographically isolated from remaining populations.

Conservation efforts have included relocating bears away from conflict situations, educating the public to prevent conflict and promote a public interest in protecting the bears, avoiding continued fragmentation of the bear population, and, as a trial, rehabilitation of orphaned grizzly cubs. The government of BC (BC Ministry of Environment), the International Fund for Animal Welfare (IFAW), and the Northern Lights Wildlife Society (NLWS) have united to rehabilitate injured or orphaned grizzly cubs. The ultimate goal of this project is for these bears to be collared and released back into the wild and studied to determine whether the animals are able to successfully integrate into wild populations without posing increased risk to people.
The American black bear, Ursus americanus, is native to North America and is the most common bear species seen on the continent. It is distributed widely across Canada, the US, and northern Mexico. The Committee on the Status of Endangered Wildlife in Canada (COSEWIC) lists the black bear as not at risk (COSEWIC 1999). Although black bears are not yet at risk, it is important to study them when individuals are accessible, such as in a rehabilitation situation, because it allows for ongoing assessment of their welfare while in captivity.

The NLWS is an established wildlife rehabilitation facility that is licensed to treat, rehabilitate, and release black bear cubs and is the first center in Canada permitted to rehabilitate grizzly bears. This pilot project aims to develop standards for raising grizzly cubs in captivity in a manner that will allow for reintroduction of healthy yearlings into the locations where they were orphaned. The goal is that these cubs will succeed at foraging and hunting after release, reintegrate into the breeding populations, and not encounter conflict with humans. Rehabilitation can be a beneficial management tool (Zarnke 2006) and rehabilitation centers offer a unique opportunity to study animals that would be difficult to sample in the 
Figure 1. Mean Leukocyte Differentials for Black Bears at The Northern Lights Wildlife Shelter

nLWS Black bear means =ISIS black bear reference means

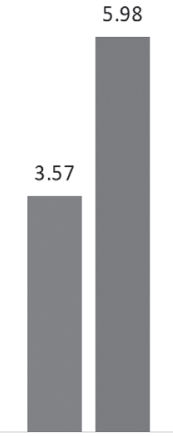

Neutrophils (x10E6/ml)

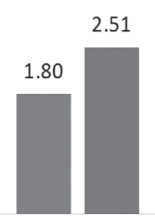

Lymphocytes $(\mathrm{x} 10 \mathrm{E} 6 / \mathrm{ml})$

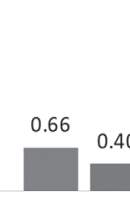

Monocytes $(\mathrm{x} 10 \mathrm{E} 6 / \mathrm{ml})$

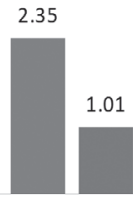

Eosinophils $(\times 10 \mathrm{E} 6 / \mathrm{ml})$
$0.01 \quad 0.01$

Basophils $(\times 10 \mathrm{E} 6 / \mathrm{ml})$
Figure 1. Mean Leukocyte Differentials for Black Bears at the Northern Lights Wildlife Shelter.

Figure 2. Leukocyte Differentials for Grizzly Yearlings at The Northern Lights Wildlife Shelter

n NLWS Grizzly Means = ISIS Grizzly Reference Means

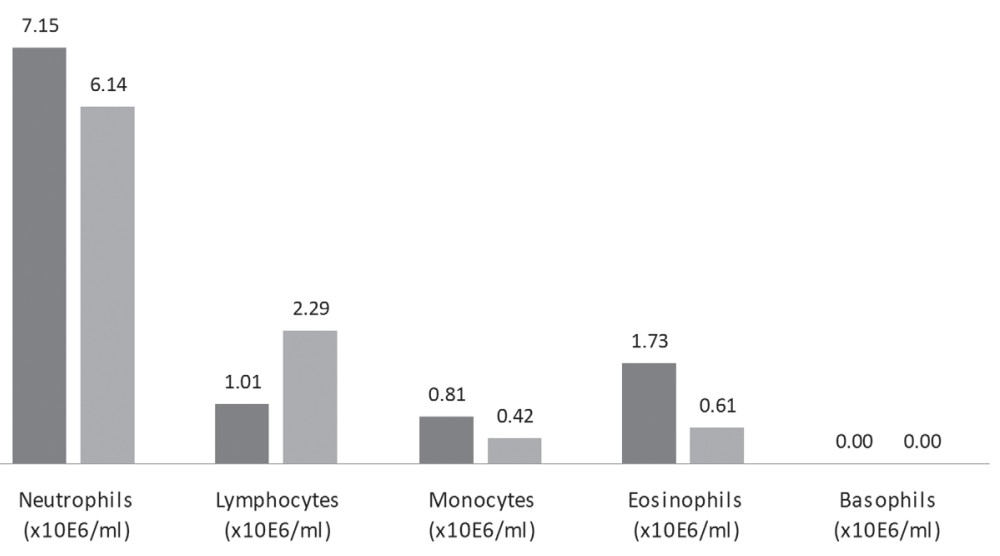

Figure 2. Mean Leukocyte Differentials for Grizzly Bears at the Northern Lights Wildlife Shelter.

wild due to factors such as the time and cost of finding and immobilizing animals. However, rehabilitation centers, despite the best intentions, cannot replicate a completely natural situation in which orphans can grow. Cubs are kept in enclosures at a higher density than would be experienced in the wild and fed a shelter-determined diet. It is important to assess the health and well being as much as possible without compromising the goal of rehabilitation that requires minimal contact with people.

The objective of this study was to establish a baseline for infectious disease prevalence in injured and orphaned griz- zly and black bear cubs held at NLWS for rehabilitation. Canine distemper, an RNA virus from the Paramyxoviridae, has been widely identified in carnivores and may be contributing to disease epidemics in felids and marine mammals (Deem 2000; Baumgartner 2003). This virus has been recorded in grizzlies at prevalences of up to 8.3 percent (Chomel 1998; Deem 2000; Baumgartner 2003; Philippa et al 2004) and in black bears at prevalences of up to 8 percent (Dunbar 1998; Philippa 2004). Canine hepatitis, an adenovirus, has been documented at 14 percent to 29 percent prevalence in Alaskan grizzlies (Chomel 1998; Zarnke 1989; Philippa 2004) and up to 6 percent prevalence in black bears (Dunbar 1998; Philippa 2004; Whetstone 1988). Toxoplasmosis was documented ranging from 9 percent of southern Alaskan to 37 percent of northern Alaskan grizzlies (Zarnke 1997; Chomel 1995; Philippa 2004) and from 15 percent (Chomel 1995; Philippa 2004; Dunbar 1998; Binninger et al 1980) to as high as 84 percent of black bears in a North Carolina study (Nutter 1998). Leptospirosis was identified in bears (Modric 1993; Binninger et al 1980; Anderson et al 1978) and has zoonotic potential.

In addition to serologic testing, baseline hematology and biochemical parameters were measured. This data contributes to health monitoring of orphaned cubs admitted to the shelter and builds awareness of possible disease agents being released back into the environment with the yearling bears. Blood chemistries and counts also help to build the library of hematological values that are used to generate normal ranges and allow the shelter to screen the metabolic status of cubs in care for nutritional and other health issues.
Table 1. Infectious Disease Results.

\begin{tabular}{|l|c|c|}
\hline Infectious Disease Results & $n$ & All Bears \\
\hline Canine Distemper Virus & 11 & $<1: 2$ \\
\hline Canine Adenovirus 1 and 2 & 10 & $<1: 2$ \\
\hline Toxoplasma gondii & 10 & Negative \\
\hline Leptospira spp. & 10 & Negative \\
\hline
\end{tabular}


Table 2. Serum Chemistry Means and Standard Deviations for Bears at the Northern Lights Wildlife Shelter.

\begin{tabular}{|l|r|r|r|r|}
\hline & \multicolumn{2}{|c|}{ Black Bear, $n=8$} & \multicolumn{2}{c|}{ Grizzly Bear, $n=2$} \\
\hline Parameter & \multicolumn{1}{c|}{ Mean } & $\underline{\text { Std. Dev. }}$ & \multicolumn{1}{c|}{ Mean } & $\underline{\text { Std. Dev. }}$ \\
\hline Glucose (mmol/L) & 4.05 & 0.82 & 4.30 & 0.42 \\
\hline Urea (mmol/L) & 3.13 & 1.61 & 2.25 & 0.35 \\
\hline Creatinine umol/L & 48.75 & 18.42 & 55.00 & 7.07 \\
\hline BUN/Creatinine (mmol/L) & 16.09 & 7.08 & 10.50 & 2.97 \\
\hline Sodium (mmol/L) & 136.13 & 1.81 & 136.50 & 0.71 \\
\hline Potassium (mmol/L) & 5.11 & 0.23 & 4.85 & 0.35 \\
\hline Cloride (mmol/L) & 101.25 & 1.28 & 100.50 & 0.71 \\
\hline Bicarbonate (mmol/L) & 19.25 & 2.92 & 22.50 & 0.71 \\
\hline Anion Gap & 20.74 & 2.53 & 18.35 & 1.06 \\
\hline Calcium (mmol/L) & 2.27 & 0.07 & 2.31 & 0.13 \\
\hline Phosphorus (mmol/L) & 2.58 & 0.48 & 2.00 & 0.01 \\
\hline Total Protein (g/L) & 59.00 & 8.26 & 73.00 & 0.00 \\
\hline Albumin (g/L) & 26.63 & 5.78 & 37.00 & 1.41 \\
\hline Globulin (g/L) & 32.63 & 4.60 & 36.00 & 1.41 \\
\hline Total Bilirubin umol/L & 2.38 & 0.52 & 2.00 & 0.00 \\
\hline ALP (IU/L) & 108.50 & 35.28 & 81.50 & 0.71 \\
\hline ALT (IU/L) & 35.13 & 3.27 & 27.50 & 3.54 \\
\hline AST (IU/L) & 94.75 & 9.84 & & \\
\hline GGT (IU/L) & 12.13 & 2.47 & 8.00 & 1.41 \\
\hline CK (IU/L) & 311.63 & 174.49 & 124.50 & 6.36 \\
\hline Amylase (IU/L) & 16.63 & 10.45 & 29.50 & 10.61 \\
\hline Lipase (IU/L) & 22.06 & 41.00 & 19.80 \\
\hline Calculated Osmolality & 6.76 & 269.50 & 0.71 \\
\hline
\end{tabular}

were killed or they were observed over an extended time without a mother. The grizzlies were kept in an enclosure separate from the black bears (8482 sq feet). Black bears were housed in four groups; two groups of four yearling bears, one group of three first year cubs, and one individual yearling bear.

Blood samples were collected from the bears throughout June and July 2009, when they were anesthetized for pre-release collaring, ear-tagging, and tattooing. The cubs were tranquilized to be moved into another enclosure and were not being released. The grizzlies were tranquilized by dart gun with $4 \mathrm{mg} /$ kg intramuscular (IM) Telazol ${ }^{\circledR}$ (tiletamine/zolazepam, Fort Doge Animal Health [now Pfizer Animal Health], Overland Park, KS) and black bears were tranquilized by pole-dart with a combination of ketamine $(5 \mathrm{mg} / \mathrm{kg}$ IM) and xylazine ( $2 \mathrm{mg} / \mathrm{kg} \mathrm{IM}$ ). Blood samples were collected via venipuncture of the femoral or cephalic vein using an 18 ga, 1.5 in needle and luer-lock $20 \mathrm{ml}$ syringe. Eighteen milliliters of blood were collected from each of the yearling bears and eight milliliters were collected from each of the young cubs. Blood was put into two EDTA tubes and three serum-separator vials and refrigerated until all samples were collected. Blood smears were made and stained using Dif-Quick (Romanowsky) stain. The serum-separator tubes were allowed to clot while in the field collecting the other samples and then centrifuged within an hour of returning from the enclosures. At least 1-ml of serum from each sample was transferred with a sterile pipette into each of three sterile, glass red-top tubes containing no preservative. The samples containing 2-ml blood in EDTA, stained blood smears, and one serum separator tube with at least 1-ml serum were refrigerated overnight and shipped to IDEXX at Langley, BC the next day. Complete blood 
Table 3. Hematology Means and Standard Deviations for Bears at the Northern Lights Wildlife Shelter.

\begin{tabular}{|c|c|c|c|c|c|c|c|c|}
\hline \multirow[b]{2}{*}{$\underline{\text { Parameters }}$} & \multicolumn{2}{|c|}{ Black Bear, $n=11$} & \multicolumn{2}{|c|}{$\begin{array}{c}\text { Black Bear } \\
\text { Reference Ranges } \\
\text { ISIS }\end{array}$} & \multicolumn{2}{|c|}{ Grizzly Bear, $n=2$} & \multicolumn{2}{|c|}{$\begin{array}{c}\text { Grizzly Bear } \\
\text { Reference Ranges } \\
\text { ISIS }\end{array}$} \\
\hline & Mean & Std. Dev. & Mean & $\underline{\text { Std. Dev. }}$ & Mean & Std. Dev. & Mean & Std. Dev. \\
\hline $\begin{array}{l}\text { White Cell Count } \\
\text { x10E9/L }\end{array}$ & 7.67 & 3.41 & 9.63 & 2.38 & 10.70 & 2.12 & 9.65 & 3.06 \\
\hline $\begin{array}{l}\text { Red Cell Count } \\
\text { x10E12/L }\end{array}$ & 6.16 & 1.01 & 7.87 & 1.19 & 6.35 & 0.21 & 6.47 & 1.32 \\
\hline Hemoglobin (g/L) & 121.67 & 21.49 & 16.00 & 2.70 & 163.50 & 2.12 & 16.70 & 2.40 \\
\hline Hematocrit (L/L) & 0.35 & 0.07 & 45.50 & 8.20 & 0.47 & 0.01 & 47.00 & 6.70 \\
\hline $\begin{array}{l}\text { Mean Corpuscular } \\
\text { Vol. ( } \mathrm{fl} \text { ) }\end{array}$ & 57.03 & 3.81 & 57.90 & 4.70 & 73.85 & 1.06 & 76.90 & 18.60 \\
\hline $\begin{array}{l}\text { Platelets } \\
\text { x10E9/L }\end{array}$ & 461.22 & 351.59 & 317.00 & 115.00 & 290.50 & 54.45 & 482.00 & 187.00 \\
\hline $\begin{array}{l}\text { Mean Platelet } \\
\text { Vol. (fl) }\end{array}$ & 9.47 & 0.86 & & & 8.35 & 0.92 & & \\
\hline $\begin{array}{l}\text { Neutrophils } \\
(\mathrm{x} 10 \mathrm{E} 6 / \mathrm{ml})\end{array}$ & 3.57 & 1.83 & 5.98 & 1.76 & 7.15 & 1.79 & 6.14 & 2.14 \\
\hline $\begin{array}{l}\text { Lymphocytes } \\
\text { (x10E6/ml) }\end{array}$ & 1.80 & 0.58 & 2.51 & 1.24 & 1.01 & 0.39 & 2.29 & 1.16 \\
\hline $\begin{array}{l}\text { Monocytes } \\
(x 10 \mathrm{E} 6 / \mathrm{ml})\end{array}$ & 0.66 & 1.12 & 0.40 & 0.30 & 0.81 & 0.23 & 0.42 & 0.33 \\
\hline $\begin{array}{l}\text { Eosinophils } \\
(x 10 E 6 / m l)\end{array}$ & 2.35 & 2.00 & 1.01 & 1.08 & 1.73 & 0.49 & 0.61 & 0.55 \\
\hline $\begin{array}{l}\text { Basophils } \\
\text { (x10E6/ml) }\end{array}$ & 0.01 & 0.03 & 0.01 & 0.00 & 0.00 & 0.00 & 0.00 & 0.00 \\
\hline
\end{tabular}

counts (CBC), manual differentials, and blood chemistries were completed at the lab. The blood chemistry analysis included measurements of: glucose, urea, creatinine, blood urea nitrogen (BUN), BUN/creatinine ratios, sodium $(\mathrm{Na})$, potassium $(\mathrm{K}), \mathrm{Na} / \mathrm{K}$ ratio, chloride, bicarbonate, anion gap, calcium, phosphorus, total protein (TP), albumin, globulin, total bilirubin, alkaline phosphatase (ALP), alanine aminotransferase (ALT), gamma-glutamyl transpepsidase (GGT), creatinine phosphokinase (CPK), amylase, lipase, and calculated osmolality.

Additionally, three red-top tubes of at least $1-\mathrm{ml}$ serum were frozen for each bear in a standard freezer at $10^{\circ} \mathrm{F}\left(12^{\circ} \mathrm{C}\right)$. Samples were collected and frozen over a two-month period so time between collection and shipment varied from six weeks to one week. After blood was drawn from all bears in the shelter, the frozen sera was collectively packed in a styrofoam cooler with frozen gel packs and shipped to the Animal Health Laboratory at the University of Guelph in Ontario for serology testing. Serologic tests for Canine Adenovirus Type 1 and 2, Canine Distemper Virus (CDV), Leptospira interrogans MAT, and Toxoplasmosis pHA were completed for ten of the bears. The Leptospira assays included seven serovars: L.autumnalis, L. bratislava, L. canicola, L. grippotyphosa, L. icterohaemorrhagiae, and L. pomona. One black bear was tested only for CDV due to limited serum. 


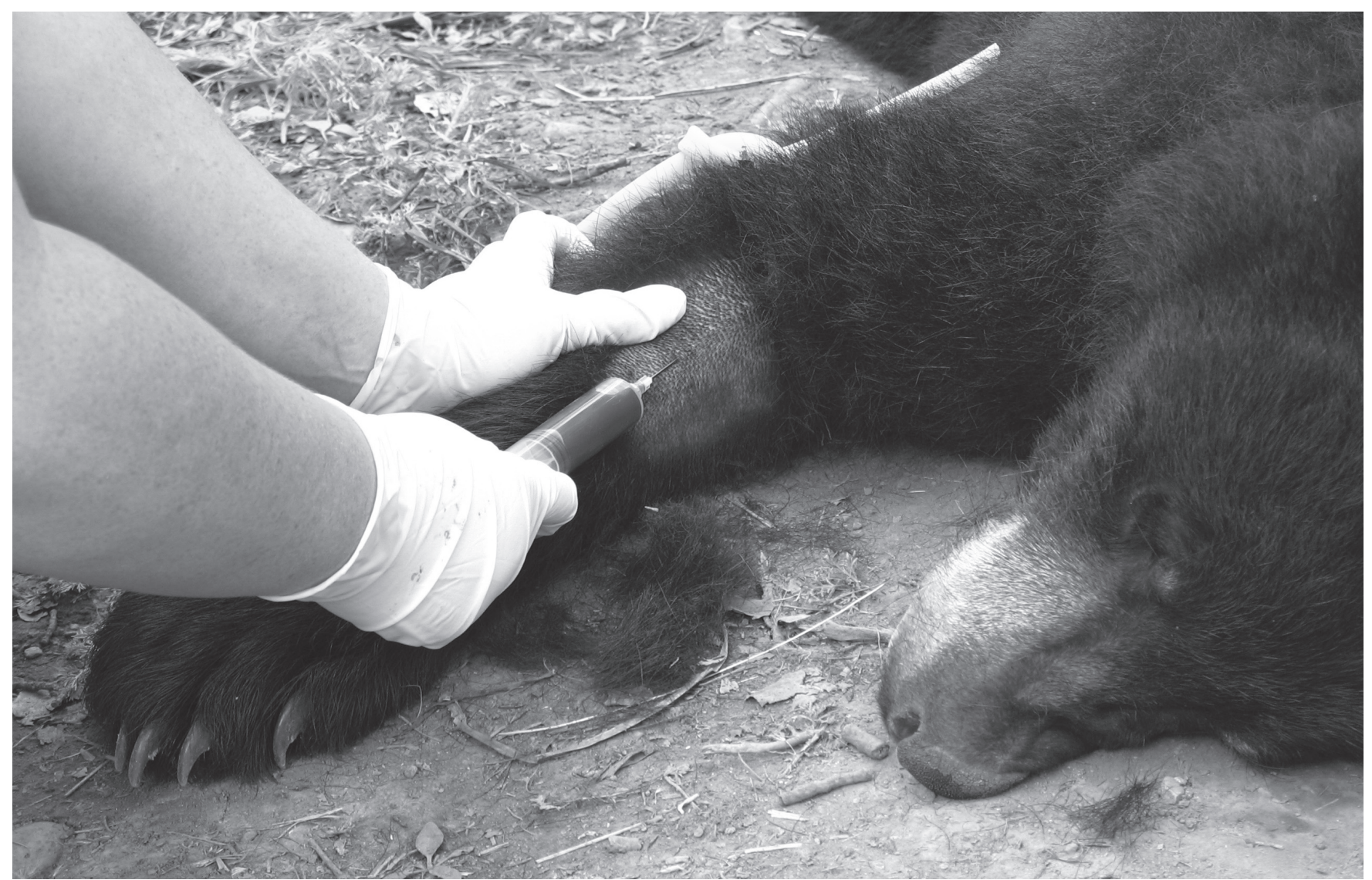

The author taking a blood sample from a sedated black bear (Ursus americanus).

The means and standard deviations were determined for the hematological and biochemical parameters.

Seroprevalence of each infectious agent in the study population was calculated. Blood chemistry and $\mathrm{CBC}$ results were compared with published normal range values by ISIS and IDEXX for grizzlies and black bears.

\section{RESULTS}

Results of this study indicated all of the orphaned cubs housed at the NLWS were negative for leptospirosis, toxoplasmosis, canine distemper, and canine adenovirus 1 and 2 based on serologic testing. Serum chemistries were obtained and the mean and standard deviation calculated for black bears. Means were not calculated for grizzly cubs due to the small sample size. Infectious disease serology is reported in Table 1. Serum chemistry values are reported in Table 2 and hematology values in Table 3. Leukocyte differential results for black bears are displayed in Figure 1, along with the mean values reported by ISIS. Leukocyte differential results for the grizzlies are displayed in Figure 2 , along with the mean values reported by ISIS.

Serum chemistries of all tested bears generally fell within the physiological reference ranges published by the ISIS (ISIS 2002) for both black and grizzly bears and by IDEXX for grizzly bears. Urea values, however, were low for both the grizzly bears (2 and 2.5 $\mathrm{mmol} / \mathrm{L}$ ) and for five of the black bears (between 0.9 and $3.5 \mathrm{mmol} / \mathrm{L}$ ), compared to the IDEXX reference range for urea for grizzlies ( 4 to $27 \mathrm{mmol} / \mathrm{L}$ ), the ISIS grizzly range $(5.48+/-1.83 \mathrm{mmol} / \mathrm{L})$, and the ISIS urea values for black bears $(5.84+/-1.83 \mathrm{mmol} / \mathrm{L})$. Phosphorus was high for only one black bear cub $(3.34 \mathrm{mmol} / \mathrm{L})$ compared to the ISIS normal of 1.87 $+/-0.387 \mathrm{mmol} / \mathrm{L}$. Table 2 illustrates that the alkaline phosphatase (ALP) was elevated in all three first year cubs and one yearling black bear with values ranging from 102 to $166 \mathrm{IU} / \mathrm{L}$ compared to the ISIS range of $41+/-30 \mathrm{IU} / \mathrm{LC}$ for black bears cubs.

Table 2 also shows that three of the black bears, a yearling and two of the first year cubs, had blood glucoses ranging from 2.6 to $3.7 \mathrm{mmol} / \mathrm{L}$ indicating that they were hypoglycemic compared to the normal ISIS range for glucose $(6.22+/-2.22)$. Additionally, four of the bears had increased CPK ranging between 385 and $588 \mathrm{IU} / \mathrm{L}$ when compared to the ISIS normal value of $146+/-90 \mathrm{IU} / \mathrm{L}$.

In the differential blood count, one almost uniform finding was eosinophilia as illustrated in Figures 1 and 2. Nine out of the eleven bears tested had elevated levels of eosinophils according to IDEXX and ISIS reference ranges. 


\section{DIscussion}

The health of bears in a rehabilitation center is affected by many factors such as bear density in each enclosure, unnatural diet, lack of maternal contact and influence, potential parasite and disease exposure from humans and other animals in the shelter, as well as contact with wild animals through the enclosure. It is important to monitor the health of grizzly and black bear cubs that are rehabilitated for reintroduction into the natural environment in order to recognize health risks to which care in captivity may contribute, to be aware of pathogens that may be released with the bears back into wild populations, and to build a database of health indicators. Although this study was not a comprehensive health analysis and was limited only to blood chemistry, cell counts, and serological testing for CDV, adenovirus, toxoplasmosis, and leptospirosis, it serves as a starting point for developing such a database and health screening at the NLWS.

The low urea seen in the grizzly bears and younger first year black bear cubs could be indicative of anorexia, inadequate protein in the diet, or individual variation. Bear diets at the shelter varied with age and number of individuals in a pen. Generally 3 to 4 individuals were kept in each enclosure and fed as a group so the precise nutritional intake for each bear was not monitored. The grizzly yearlings were fed a diet of dry adult maintenance dog food, fruits, vegetables, donated breads, as well as fresh picked dandelions, grasses, and purple vetch. The yearling black bears were fed a similar diet although they received only half the amount of dog food as black bears are believed to require less protein than the more carnivorous grizzlies. First year cubs were fed fruits, breads, oatmeal, baby formula, and evaporated milk. By the end of the summer, some dog food and grasses had been added to the diets as well. All bears were fed twice daily by scattering food throughout the enclosures and allowing them to forage during the day. Low BUN values may indicate a need for additional protein to be added into the diets. In the wild, grizzlies would be eating very broad diets that vary with location. The wild diet includes foods such as insect larva, ants, roots, berries, vegetation such as sweet vetch, cow parsnips, seasonal berries, fish, carrion, and the local prey species, which may include rodents, deer, elk, and moose (Munro et al 2006). Zoos feed a variety of diets. An example from Woodland Park Zoo is: dog food, yams, carrots, apples, leafy greens, berries, omnivore biscuits, and bread (WPZ 2009). Low urea nitrogen and urea creatinine values have been reported in other populations of wild black bears in the fall due to seasonal changes in food sources with different nutritive content (Eagle and Pelton 1983; Hellgren et al 1989; 1997; Kusak et al 2005). Additionally, lower BUN values have been reported in captive bears compared to wild counterparts (Kusak et al 2007).

Phosphorus was higher for all three 5 to 6 month old cubs, although only one was higher than the reference range. Possible rule-outs include age-related differences in blood values and dietary imbalance. Alkaline phosphatase also was elevated in these bears. It has been suggested that younger bears frequently have higher phosphorus and ALP due to age-related high rate of bone growth and remodeling (Brannon 1985; Schroeder 1987; Hellgren et al 1997).

The bears had not been fed the morning that they were darted and this may explain the low blood glucose. It is unlikely to be an artifact of blood collection as the serum was separated from the red blood cells within a few hours. The stress of capture also has an effect on serum glucose, which decreases this parameter's accuracy in predicting bears' normal physiological values (Hellgren et al 1989).

Elevated CPK is a marker of muscle damage and may be due to tissue trauma caused by the intramuscular injection of ketamine and xylazine for sedation and capture stress (Kusak et al 2005).

Diets fed in a rehabilitation environment are limited to a degree by funding, volunteers, and availability of food items. Shelters that run on monetary and food donations carefully balance the need to provide as natural and nutritious a diet as possible with the economic challenge of rehabilitating bears with limited resources. Rehabilitation seeks a compromise between the benefits of being able to save individual bears for reintroduction into the wild and the limitations of providing natural diets and environments to bears while in captivity. It is poorly documented how these bears fare after reintroduction; rehabilitation programs would benefit greatly by future research that continued to assess the bears' health and behavior after release. Such monitoring would allow rehabilitation centers to assess their programs and make adjustments to diet, environment, and behavioral enrichment as needed.

In the differential leukocyte counts, one almost uniform finding was eosinophilia. Nine out of the eleven bears tested had elevated levels of eosinophils according to IDEXX and ISIS reference ranges. Differential diagnoses for eosinophilia include both allergic and parasitic diseases. Tapeworms were observed in at least one black bear yearling. This bear was treated twice with Drontal ${ }^{\circledR}$ Plus (praziquantel/ pyrantel pamoate/febantel, Bayer Animal Health, Shawnee Mission KS) hidden in food items; however, 
the need for minimal contact with the bears prevented her from being accurately weighed for dosage calculations. Failure to estimate weight accurately may lead to insufficient treatment programs. Previous studies also have noted that eosinophils were more numerous in captive bears than in free-living bears (Kusak et al 2005). This may be due to young bears being kept at high densities where they are likely to contract parasites from each other and also due to difficulty in sterilizing enclosures between groups of bears. An attempt is made to remove all fecal material from the previous occupants before bears are moved into a new enclosure at the shelter. Due to the earthen floor, tree trunk climbing enrichments, and porous wooden dens it is unlikely that all parasites are removed between groups of bears. This study originally had planned to complete fecal analysis of the bears; however, supplies for doing so were retained at the airport and not allowed into BC. We were unable to order new materials in time to complete fecal analysis before the bears were released. Using magnesium sulfate heptahydrate, Epsom salt, as a floatation medium was attempted without success, likely due to the inability to accurately calculate specific gravity of the solution in the field.

Previous studies have identified many infectious diseases occurring in grizzly and black bear populations; however, most of the data reported has been collected from Alaskan bears. There is a gap of information in the literature on disease prevalence in bear populations in $\mathrm{BC}$, emphasizing the importance of the limited data collected from these bears in rehabilitation. This study was confined to testing the grizzly and black bears for canine adenovirus, Leptospira interrogans, Toxoplasma, and canine distemper. Seroprevalence for these infections was negative in all of the bears housed at NLWS. This is encouraging as it was suspected that two shelter cubs died of canine distemper the previous year (Angelika Langen, NLWS, Smithers, $\mathrm{BC}$, personal communication). Cubs are isolated for a variable period of time on arrival at the shelter before introduced to a group; however, all bears potentially may have contact with wild bears through the enclosure wire walls.

Additionally, serosurveillance for antibodies in grizzlies and black bears have documented exposure to infectious agents including: brucellosis, B. suis documented in grizzlies (Chomel 1998; Murray et al 1999; Zarnke 2006; Neiland 1975; Godfroid 2002) and antibodies against Brucella spp. also reported in black bears (Chomel 1998; Dunbar 1998; Binninger et al 1980), tularemia (Chomel 1998; Binninger et al 1980); trichinellosis (Chomel 1998; Zarnke 1997; CDC MMWR 2003; Schellenberg 2003; Binninger et al 1980); Eastern, Western, Venezuelan, and St. Louis Encephalitis, Q fever (Coxiella burnetii) (Dunbar 1998; Binninger et al 1980), Phocine distemper virus (Philippa 2004); Lyme disease (Philippa 2004); Yersinia pestis (Clover et al 1979), and Rocky Mountain spotted fever (Binninger et al 1980). Trichinella also has been directly observed at necropsy and cysts can be isolated after muscle digestion (Murray et al 1999, Zarnke 1997). Brucella has been isolated and documented to cause pathology (Murray et al 1999; Neiland 1975). Brucella infection is especially a concern in threatened populations as it causes abortion and infertility in many species and may interfere with reproduction rates. It is believed that carnivores become infected with brucellosis after ingesting infected prey animals (Murray et al 1999). There is sparse documentation of many infections actually causing pathology in freeliving bear populations. This may be due to the difficulty of carcass recovery when diseased bears have died in the wild (Murray et al 1999). Measurements of the prevalence of these diseases may be included in future studies.

In addition to increasing the surveillance for infectious diseases in cubs being taken into the shelter, it would be valuable for future studies to complete fecal analyses. The high prevalence of eosinophilia found in this study is suggestive of parasitic disease within the shelter environment. Fecal smears and flotation could identify any gastrointestinal parasites in the bears, and dilute egg counts could quantify the parasite load to determine whether it is higher than would be expected in wild young bears. The high density at which it is necessary to keep the bears in a shelter environment and the inability to completely sterilize enclosures between bear groups may be increasing the parasite prevalence. Identifying the parasites also would help the shelter to further develop the parasite treatment protocol.

Large carnivores such as bears are important to ecosystem stability and often serve as keystone species. Therefore, it benefits the entire ecosystem to maintain healthy populations of these species (Murray 1999). Disease surveillance contributes to informed management and conservation practices. It is essential to develop a baseline of infectious and parasitic disease prevalence so that changes in prevalence, new outbreaks, and other risk factors are recognized. It is also important to be aware of what pathogens may be released back into native wildlife populations as a result of rehabilitation programs. Currently, there is no baseline data reported for infectious disease prevalence in grizzly and black bear populations in BC. The sample size in this study is small and limited 
only to bears under two years of age, which prohibits inferences from being drawn and applied to the whole bear population in $\mathrm{BC}$. However, the information collected in this study does contribute to building a larger future database and help the NLWS to monitor aspects of bear health while in their care.

\section{ACKNOWLEDGEMENTS}

The author gratefully acknowledges Angelika and Peter Langen, of the Northern Lights Wildlife Society, for their help and for allowing access to bears in their care; Dr. Helen Schwantje and the British Columbia Ministry of Environment, Land, \& Parks; the International Fund for Animal Welfare; Dr. Flo Tseng, Tufts University Cummings School of Veterinary Medicine; Dr. Jani Clougher for assistance in obtaining samples; Dr. Michael Des Harnais and the Babine Pet Hospital for use of his facility; Carolyn Corsiglia, Dr. Mark Pokras at Tufts University, and Michael Thomas. This project was generously funded by a research grant from Tufts Center for Conservation Medicine.

\section{LITERATURE CITED}

Anderson, D. C., J. G. Geistfeld, H. M. Maetz, et al. 1978. Leptospirosis in Zoo Workers Associated with Bears. American Journal of Tropical Medicine and Hygiene. Jan 27. (1): 210-211.

Baumgärtner, W., S. Alldinger, A. Beineke, et al. 2003. Canine Distemper Virus-An Agent Looking for New Hosts. Dtsch Tierarztl Wochenschr. Apr 1. 10(4): 137-142.

Binninger, C. E., J. J. Beecham, L. A. Thomas, et al. 1980. A Serologic Survey for Selected Infectious Diseases of Black Bears in Idaho. Journal of Wildlife Disease. Jul 16. (3): 423-430.

Brannon, R. D. 1985. Serum Chemistry of Central and Northern Alaska Grizzly Bears. Journal of Wildlife Management. 49: 893-900.

CDC MMWR. Centers for Disease Control, Morbidity and Mortality Weekly Report. 2003. Trichinellosis Surveillance-United States, 19972001. In CDC Surveillance Summaries (No. SS-6): $1-8$.

CDC MMWR. Centers for Disease Control, Morbidity and Mortality Weekly Report. 2004. Trichinellosis Associated with Bear Meat-New York and Tennessee, 2003. Centers for Disease Control and Prevention. Jul 16. 53(27): 606-610.
Chomel, B. B., R. W. Kasten, G. Chappuis, et al. 1998. Serological Survey of Selected Canine Viral Pathogens and Zoonoses in Grizzly Bears (Ursus arctos horribilis) and Black Bears (Ursus amerincanus) from Alaska. Revue Scientifique et Technique. Dec 17. (3): 756-766.

Chomel, B. B., R. L. Zarnke, R. W. Kasten, et al. Serologic Survey of Toxoplasma gondii in Grizzly Bears (Ursus arctos) and Black Bears (Usrus americanus), from Alaska, 1988 to 1991. Journal of Wildlife Disease. Oct 31. (4): 472-479.

Clover, J. R., T. D. Hofstra, B. G. Kuluris, et al. 1989. Serologic Evidence of Yersinia pestis Infection in Small Mammals and Bears from a Temperate Rainforest of North Coastal California. Journal of Wildlife Disease. 25: 52-60.

COSEWIC. Committee On The Status of Endangered Wildlife in Canada [Species at Risk Public Registry website]. 2002. Species Profile for Grizzly Bear Northwestern Population. [cited 2009 Feb. 28] Available from: <http://www.sararegistry. gc.ca/species/speciesDetails_e.cfm?sid=639>.

COSEWIC. Committee On The Status of Endangered Wildlife in Canada [website]. 1999. Species profile for American Black Bear, Ursus americanus, \#511. [cited 2009 Feb 28]. Available from: 〈http://www.sararegistry.gc.ca/species>.

Deem, S. L., L. H. Spelman, R. A. Yates, et al. 2000. Canine Distemper in Terrestrial Carnivores: A Review. Journal of Zoo and Wildlife Medicine. Dec 31. (4): 441-451.

Dunbar, M. R., M. W. Cunningham, J. C. Roof. 1998. Seroprevalence of Selected Disease Agents from Free-ranging Black Bears in Florida. Journal of Wildlife Disease. Jul. 34(3): 612-619.

Eagle, T. C., M. R. Pelton. 1983. Seasonal Nutrition of Black Bears in the Great Smoky Mountains National Park. International Conference on Bear Research and Management. 5: 94-101.

Gau, R. J., S. Kutz, B. T. Elkin. 1999. Parasites in Grizzly Bears from the Central Canadian Arctic. Journal of Wildlife Disease. Jul. 35(3): 618-621.

Godfroid, J. 2002. Brucellosis in Wildlife. Revue Scientifique et Technique. Aug 21. (2): 277-286.

Hellgren, E. C., D. S. Maehr, D. L. Doan-Crider. 1997. Serum Chemistry of Southern Populations of Black Bears (Ursus americanus). American Midland Naturalist. 137: 95-105.

Hellgren, E. C., L. L. Rogers, and R. L. Kirkpatrick. 1989. Seasonal Patterns in Physiology and Nutrition of Black Bears in Great Dismal Swamp, Virginia-North Carolina. Canadian Journal of Zoology. 67: 1837-1850. 
IFAW. International Fund for Animal Welfare [website]. Grizzly Bear Rehabilitation Project. [cited 2009 Feb. 28] Available from: <http://www.ifaw. org/ifaw_canada_english/join_campaigns/national_and_regional_efforts/grizzly_bear_rehabilitation_project/index.php>.

ISIS. International Species Information System. 2002. Physiologic Reference Ranges Ursus arctos, Both Sexes Combined; Ages 8 Days to 5 Years. Reference Ranges for Physiological Values in Captive Wildlife [cd rom]. International Species Information System: Apple Valley, MN.

Kusak, J., B. R. Renata, Z. Zdravko et al. 2007. Effects of Sex, Age, Body Mass, and Capturing Method on Hematologic Values of Brown Bears in Croatia. Journal of Wildlife Disease. 41(4): 843-847.

MELP. Ministry of Environment, Lands, and Parks, British Columbia. [Environmental Stewardship Division website]. 2004. Recovery Plan for the Grizzly Bear in the North Cascades of British Columbia. North Cascades Grizzly Bear Recovery Team Report. [cited 2009 Sept. 13]. Available from: < http://www.env.gov.bc.ca/wld/grzz/\#ncgb >.

Modrić, Z., and D. Huber. 1993. Serologic Survey for Leptospriae in European Brown Bears (Ursus arctos) in Croatia. Journal of Wildlife Disease. Oct 29. (4): 608-611.

Monro, R. H. M., S. E. Nielsen, M. H. Price, et al. 2006. Seasonal and Diet Patterns of Grizzly Bear Diet and Activity in West-central Alberta. Journal of Mammology. 87(6): 1112-1121.

Murray, D. L., C. L. Kapka, J. F. Evermann, et al. 1999. Infectious Disease and the Conservation of Free-ranging Large Carnivores. Animal Conservation. (2): 241-254.

Neiland, K. A. 1975. Further Observations on Rangiferine Brucellosis in Alaskan Carnivores. Journal of Wildlife Disease. Jan. 11(1): 45-53.

NLWS. Northern Lights Wildlife Society [website]. [cited 2009 Feb. 28] Available from: < http://wildlifeshelter.com/about.htm >.

Nutter, F. B., J. F. Levine, M. K. Stoskopf, et al. 1998. Seroprevalence of Toxoplasma gondii and Trichinella spiralis in North Carolina black bears (Ursus americanus). Journal of Parasitology. Oct 8. 4(5): 1048-1050.

Pelton, M. R. 2003. Black Bear. Pp. 547-555 in Wild Mammals of North America, Biology, Management, and Conservation, 2nd edition. (G. A. Feldhamer, B. C. Thompson, and J. A. Chapman, editors). John's Hopkins University Press: Baltimore, MD.
Philippa, J. D., F. A. Leighton, P. Y. Daoust, et al. 2004. Antibodies to Selected Pathogens in Free-Ranging Terrestrial Carnivores and Marine Mammals in Canada. Veterinary Record. July 31. 155(5): 135-140.

Schellenberg, R. S., B. J. Tan, J. D. Irvine, et al. 2003. An Outbreak of Trichinellosis Due to Consumption of Bear Meat Infected with Trichinella nativa, in 2 Northern Saskatchewan Communities. Journal of Infectious Disease. Sep 15. 188(6): 835-843.

Schwartz, C. C., D. M. Sterling, M. A. Haroldson. 2003. Grizzly Bear. Pp. 556-586 in Wild Mammals of North America, Biology, Management, and Conservation, 2nd edition. (G. A. Feldhamer, B. C. Thompson, J. A. Chapman, editors). John's Hopkins University Press: Baltimore, MD.

WPZ. Woodland Park Zoo [website]. 2009. Ursus arctos Fact Sheet. [cited 2009 Sept 17] Available from: < http://www.zoo.org/factsheets/brown_bear/ brownBear.html >.

Whetstone, C. A., H. Draayer, J. E. Collins. 1988. Characterization of Canine Adenovirus Type 1 Isolated from American Black Bears. American Journal of Veterinary Research. June 4. 9(6): 778-80.

Zarnke, R. L., J. P. Dubey, O. C. Kwok, et al. 1997. Serologic Survey for Toxoplasm gondii in Grizzly Bears from Alaska. Journal of Wildlife Disease. Apr. 33(2): 267-270.

Zarnke, R. L., and M. B. Evans.1989. Serologic Survey for Infectious Canine Hepatitis Virus in Grizzly Bears (Ursus arctos) from Alaska, 1973-1987. Journal of Wildlife Disease. Oct. 25(4): 568-573.

Zarnke, R. L., R. Gamble, R. A. Heckert, Et al. 1997. Serologic Survey for Trichinella spp. in Grizzly Bear from Alaska. Journal of Wildlife Disease. Jul. 33(3): 474-479.

Zarnke, R. L., J. M. Ver Hoef., and R. A. DeLong. 2006. Geographic Pattern of Serum Antibody Prevalence for Brucella spp. in Caribou, Grizzly Bears, and Wolves from Alaska, 1975-1998. Journal of Wildlife Disease. Jul. 42(3): 570-577. (⿶.망 